\title{
8. A New Role for Government? Trends in social policy preferences since the mid-1980s
}

\author{
Shaun Wilson, Gabrielle Meagher and Kerstin Hermes
}

Three big problems - an economic crisis, failing infrastructure and adverse climate change - are reminders of the limits of market coordination and the need for active government, a role anticipated by the public and acknowledged by former Prime Minister Kevin Rudd (2009a). How have public expectations of government adjusted in awareness of these new challenges? Have voters come to expect a larger, or perhaps differently focused, role for government? Fortunately, more than 20 years of comparative survey research data provide opportunities to judge shifts in public opinion - over time and against trends evident in other countries (see, for example, Smith 1987). They also provide basic indicators of support for government activity at a time when the public's expectations of government are likely to be transformed by the economic crisis that emerged in 2008.

Our chapter looks closely at the International Social Survey Program's 'Role of Government Module 2006', ', placing Australia over time and comparatively. We begin by examining Australian preferences for government to spend more or tax less. Data on this question go back to the 1960s, allowing us to explore changes in fiscal mood. We are also able to track the shift in fiscal mood against other social indicators that move over time: attitudes to the death penalty, immigration and union power. The second part of the chapter examines spending preferences between 1985 and 2006 to discover what policy areas the Australian public most wants government to spend more on now, and how our priorities have changed over the past two decades. In the third part of the chapter, we examine what Australians believe are the government's responsibilities in key areas such as controlling prices, finding people jobs, and providing housing and for people in retirement. We look at how these beliefs have changed-or not changedover time, and compare Australian perspectives with those of citizens of other International Social Survey Program (ISSP) member countries.

1 The ISSP has fielded a Role of Government (RoG) module four times: in 1985, 1990, 1996 and 2006. In Australia, RoG was fielded with the AuSSA 2007. 


\section{Australians want more social spending}

The Australian Survey of Social Attitudes (AuSSA) series has tracked spending and taxing preferences since 2003. Over this period, preferences for more social spending have increased and, correspondingly, preferences for cutting taxes have continued to weaken. This trend coincides with a number of political and policy developments during a long period of fiscally conservative government led by John Howard (1996-2007), which tends to produce a shift in public opinion in favour of spending (for the general argument, see Stimson 2004, 76-87). In real terms, this shift in mood coincided with a slowing expansion of welfare spending - after a period of rapid increase under the previous Labor government (see Table 8.1). Indeed, between 2000 and 2005, Organisation for Economic Cooperation and Development (OECD) figures suggest a significant slowdown in welfare spending increases in Australia. Additionally, a series of income tax cuts, which have continued under the Labor Government (2007-), have limited demand for further reductions at a time when voters believe public infrastructure is deteriorating (OECD 2008). Let's take a closer look.

\section{Trends in welfare spending and taxation}

Table 8.1 presents evidence of the shifting fiscal situation since 1985. The table shows social spending by government across a range of policy areas, as a proportion of gross domestic product (GDP). Overall, Australia's public welfare spending remains below OECD averages; in 2005, it was ranked twentieth out of a list of 29 (mostly wealthy) democracies. In comparative terms, Australia is most generous in the area of family income support, with spending at 2.8 per cent of GDP, and a rank of eighth out of 29. This is the result of active policy change: the Hawke and Keating Labor governments (1983-96) expanded this area of assistance and the Howard Government preserved this program. This additional spending has had a real impact on overall and child poverty rates (Harding and Szukalska 1999), although child poverty is still significant; a recent UNICEF study ranked Australia thirteenth out of 23 OECD countries and below average on a composite index of child material wellbeing (UNICEF 2007,4).

Meanwhile, poverty among older Australians remains very high by international comparisons; in 2000, Australia was exceeded only by transitional Ireland in a study of 17 rich democracies (Mishel, Bernstein and Shierholz 2008, 384). It is easy to understand why: comparatively low spending (twenty-third out of 29) on old-age benefits evident in Table 8.1. This remains true even if we had included private spending on superannuation in the comparisons. It is not surprising, then, that Australians have strong preferences for spending more on 
age pensions; a recent Australian Election Study (AES) finding suggests 63 per cent of respondents believe that retired people with no superannuation deserve more assistance from the government (see Wilson, Meagher and Hermes 2012). Moreover, compared with 25 years ago, now older Australians have emerged as a strong constituency for more social spending. This new constituency for a more generous welfare state has made its impact: upon its election in November 2007, the new Labor government almost immediately faced demands to raise basic pension rates.

Table 8.1 suggests a slowing trend in social spending under the Howard Government compared with the previous Labor governments: compare the 4.1 per cent increase between 1985 and 1995-10 years of Labor - with just a 0.5 per cent increase between 1995 and 2005, 10 years of the Coalition. All the increase in welfare spending under Howard occurred during the first two terms of his government. The slowdown since is partly accounted for by labour, housing and asset markets that remained buoyant until 2007 and which, in turn, reduced fiscal pressures on unemployment, family and pension programs. But slower innovation in welfare policy compared with the previous government - Labor introduced Medicare, a new system of family payments and new benefits for students and for people living with disabilities - also contributed to the slowing of spending growth as well. By contrast, the Coalition's innovations concentrated on middle-class benefits - financed as tax expendituresto subsidise private health care, child care and private retirement incomes (see SpiesButcher and Stebbing 2008).

Table 8.1 also tells something of the tax story - at least in aggregate terms. Overall the tax take barely rose under Labor between 1985 and 1995 (0.5 per cent). Clearly, the Labor administration accepted a hard tax constraint, and attempted to reorganise welfare and government along 'Labor lines' within this constraint. The aggregate tax take under Howard actually increased, from 29 to 31 per cent - not a trend that would prompt voters to lose interest in tax reductions. Here, some extra detail helps to interpret the possible role of tax policy in the shifting fiscal mood in favour of spending. First, the tax expansion under Howard appears to have been more cyclical than discretionary. True, his government did broaden the tax base by introducing the goods and services tax (GST) in 2000, which helped finance a series of well-publicised income tax cuts that mostly benefited higher income earners and reduced the redistributive impact of income taxes (Vu, Harding and Percival 2008). But consumption and income taxes remained - measured as a share of GDP-fairly steady over the Howard years (see OECD 2007, p. 80). Instead, revenue growth came from rising corporate tax receipts produced by strong profitability in the private economy (OECD 2007, p. 81). Given this, the tax 'burden' faced by voters either stayed the same or decreased for higher income earners - despite growing tax revenues. 


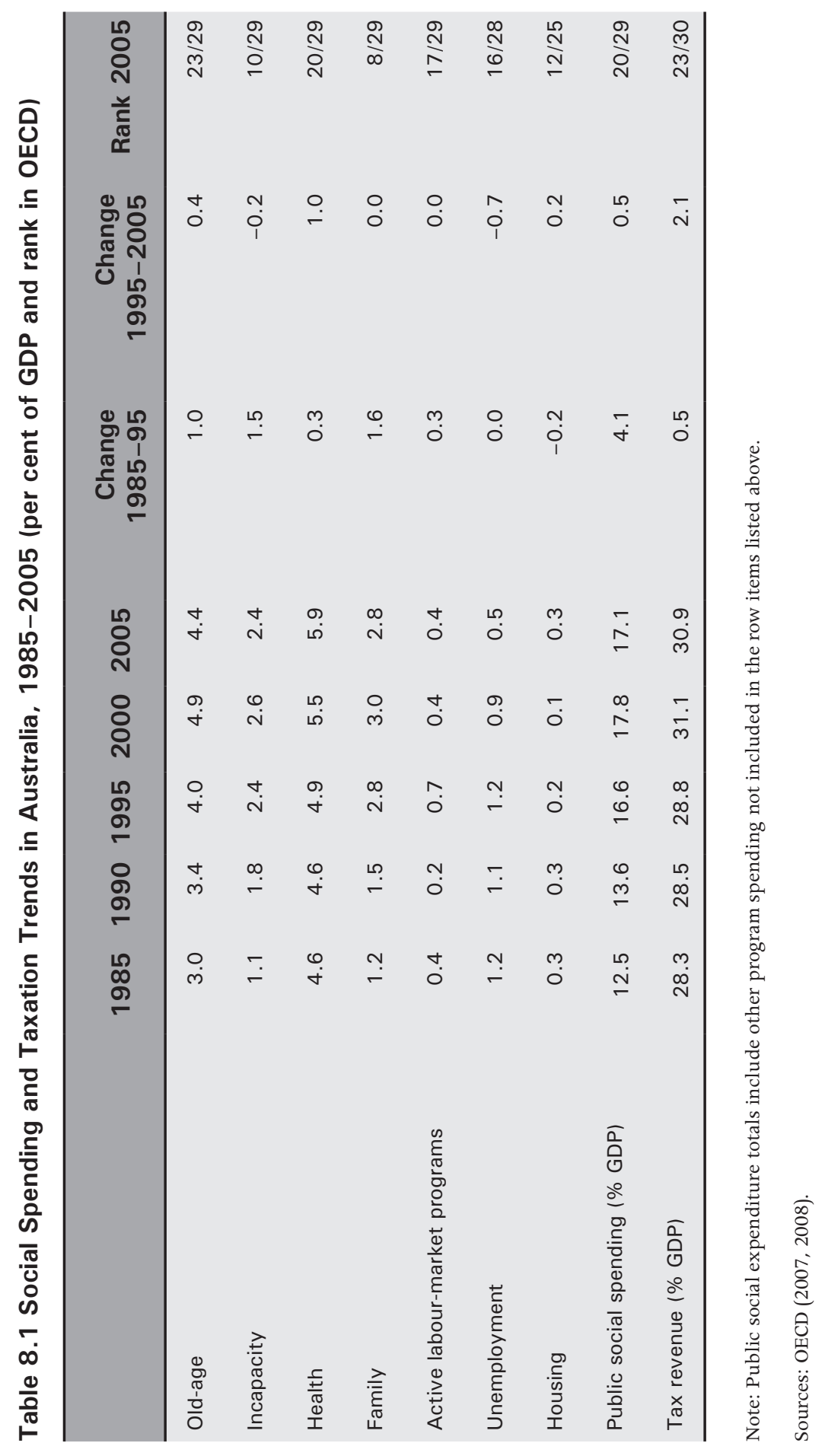


Second, when the tax expansion under the Howard Government is viewed comparatively, it was relatively modest anyway: between 1995 and 2005, the average tax take among OECD countries increased about 4 per cent of GDP compared with Australia's 2 per cent. In general terms, most OECD governments were busy expanding tax revenues to meet similar challenges as those Australia faced, only at a faster rate. Moreover, when the comparisons are pushed a bit further - and Australia's rank in the OECD over time is considered-we see that Australia continues to fall in the tax stakes, from sixteenth (out of 26 countries) in 1985 to twenty-third (out of 30) in 2005 (see Table 8.1). None of the new entrants between 1985 and 2005 could be considered a 'high tax country' and a number overtook Australia over the 20-year period surveyed (Iceland, Spain, Portugal, Switzerland and Turkey) while others (South Korea and Greece) closed the gap (see OECD 2007, p. 19). Given pressures on governments that led to the growth of revenues elsewhere, the Australian Government managed to contain the growth of government - at least in comparative terms - more than the headline figures suggest.

The upward shift in spending preferences is probably more than a symbolic reaction against the 'fiscal conservatism' of the Howard years. Social spending grew slowly, and fell in GDP terms between 2000 and 2005; the focus was on cutting income taxes and broadening the tax base. Our argument is this: policy settings have led to public pressures to improve services that now strongly exceed pressures to deliver tax relief. This policy backdrop, we think, provides the best context in which to read public opinion. The AuSSA 2007 did not include the standard item on tax and spending preferences, so here we use a similar AES measure for which we have a time series dating back to 1987. The question asked is: 'If the government had a choice between reducing taxes or spending more on social services, which do you think it should do?' The five options are: strongly favour/mildly favour reducing taxes; depends; and mildly/ strongly favour spending more on social services (see Table 8.2). 


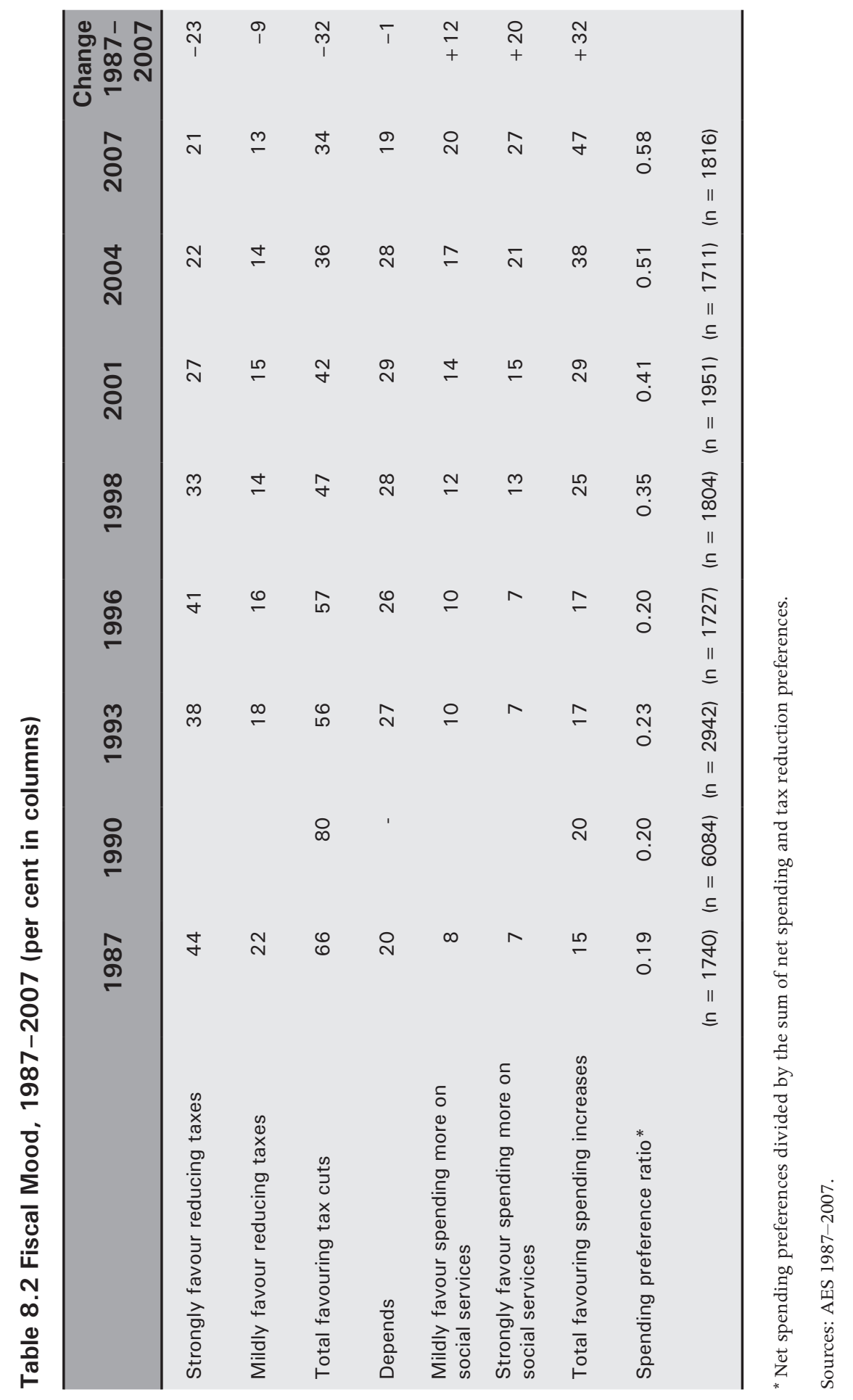


On the AES measure, the public continues to prefer attention to the spending side of government. The AES 2007 records the strongest preferences in favour of greater spending (on social services) in the series that commenced in 1987, with 47 per cent preferring more spending and 34 per cent now interested in tax cuts. This contrasts with just 10 per cent seeking more spending in 1987, when Labor (and others) were advocating spending constraint. To put spending trends in historical perspective, we have calculated a measure of spending preferences (see note to Table 8.2) and, on that score, Australians are now the most prospending they have been since the late 1960s (for earlier data, see Wilson, Meagher and Breusch 2005, p. 105). The fiscal mood provides opportunities for the Gillard Labor Government to increase social spending with one less constraint at least - that of general public opinion. And, with the scale of the global economic crisis, we can anticipate that the mood for spending has some way to run yet. We turn to the more specific question of what Australians prefer government to spend more on in the next section.

\section{Are Australians seeking greater social protection? Spending preferences compared}

We can compare trends in preferences for social spending against other social trends for which there are comparable time points. Here, we choose three others: attitudes to the death penalty, attitudes to union power and attitudes to immigration levels. The data points are for 1987 to 2007, taking account of 20 years of public opinion. We would expect attitudes to union power and immigration levels to be cyclical or 'mood' variables - that is, to fluctuate as the public moves through more liberal and more conservative moods (Stimson 1991, 2004). Over time, unions go through periods of power and influence as well as weakness and marginalisation - both are eventually registered by the public. Equally, support for immigration varies with the economic and employment cycle: as employment rises, economic resistance to immigration falls and vice versa. Attitudes to the death penalty are more complicated: they exhibit elements of a secular trend with a cyclical component - that is, long-term social change is probably permanently reducing support for capital punishment, but trends in the crime rate and publicity about serious crimes will have an impact on support or opposition at the margins. 


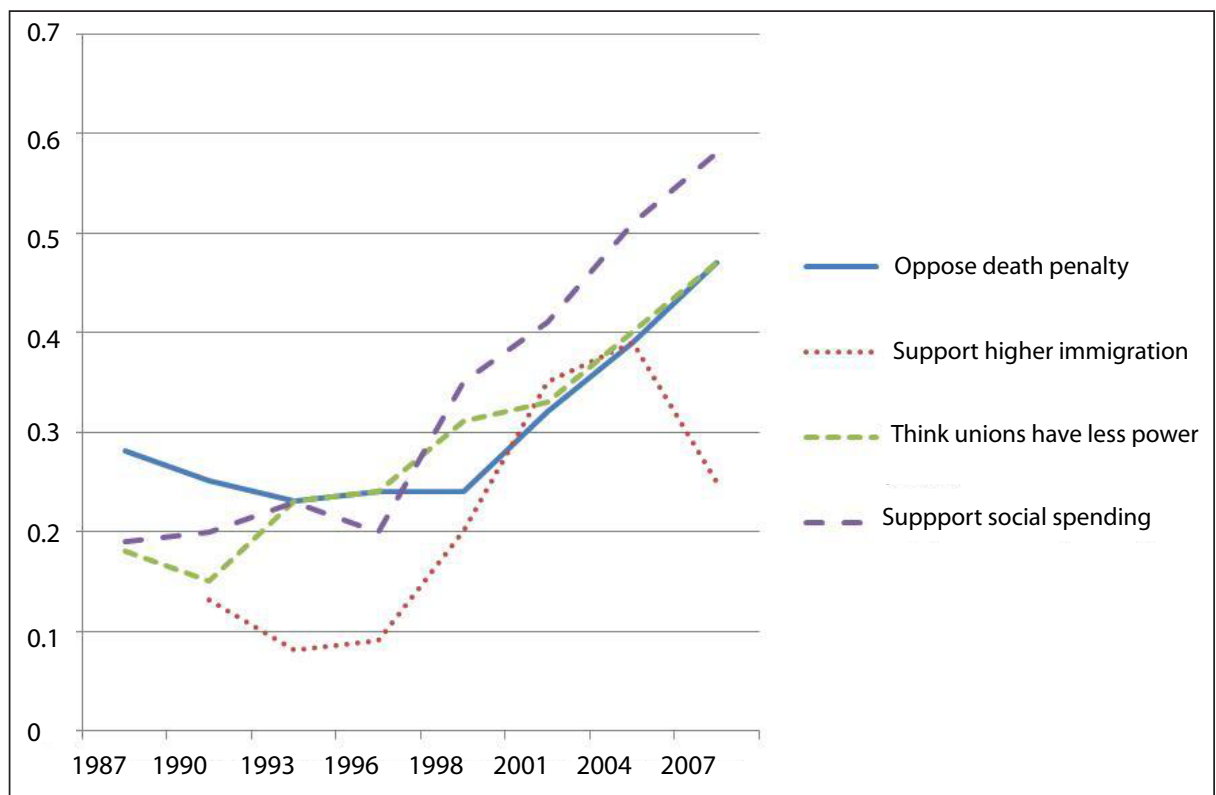

Figure 8.1 Pro-Spending Preferences: Part of a more liberal mood, 1987-2007

Notes: Figure 8.1 reports scores between 1987 and 2007 measuring: preferences for greater social spending, reduced support for the death penalty, support for more immigration, and perceptions that unions do not have too much power. Rising scores, on a scale between 0 and 1 , indicate a more liberal aggregate response to each item. The scores have been calculated as ratios of support against opposition for each proposition specified above (see Appendix Table A8.2 for details of the calculations and the scores).

Sources: AES 1987-2007.

Do any of these social trends follow closely the trend for spending? Figure 8.1 reports scores between 1987 and 2007 measuring: preferences for greater social spending, reduced support for the death penalty, support for more immigration, and perceptions that unions do not have too much power. The scores have been calculated as ratios of support against opposition for each proposition specified above (see Appendix Table A8.2 for details of the calculations and the scores). We find that, between 1987 and 2004, all four variables tend to trend together. We can conclude that, taken together, they suggest a latent 'liberal' or even social-democratic mood gathered strength during the Howard years, most likely as a balancing response to that government's perceived fiscal and social conservatism.

In 2007, however, support for immigration started to fall, departing from the continuing upward trend for the other three variables. This downward turn in support for immigration levels suggests that, as recent high immigration intakes began to coincide with rising living standard pressures, the public tempered their generosity towards immigration levels, reversing a very liberal mood apparent since the early 2000s. But this decline in support for immigration may 
well correspond with a trend that supports social spending and recognises the weakness of unions. One possible reading of the combined trend is that, after the Howard years, Australians want governments to deal with pressures on living standards, with a greater emphasis on social protection in welfare and providing a strengthened voice and rights in the workplace. The same stresses on living standards that stimulate demand for social protection may also account for the more protectionist (that is, restrictive) stance towards immigration evident in 2007.

Declining support for the death penalty reflects the more liberal mood prevailing in Australia, but secular decline in support for capital punishment will probably mean that this trend will continue long after a broader trend back to political conservatism is established. On that score, it will be interesting to see how long it takes for a more political conservative mood to emerge - as a response to the Rudd Government's increases in welfare spending (partly in response to the economic crisis of 2008 and 2009) and its restoration of a role for unions in new industrial laws (Gillard 2008; Rudd and Gillard 2007). The mitigating impact of the global economic crisis, however, will probably mean that the public seeks more protection from government, and for longer, than the political mood cycle would normally accommodate.

\section{Public priorities: Where do Australians most want additional spending?}

As we have suggested, in 2007 Australian voters were in the mood for fiscal expansion. Combined with Labor in office and reduced elite opposition to fiscal activism at a time of crisis, conditions supported an expansion in the size and role of government. But voters have supported more spending for quite some time, so it is useful to identify those areas where voters expect the largest 'catch-up' from politicians. As part of the regular Role of Government module, the ISSP has asked respondents in member countries since the mid-1980s to nominate areas of government where they would prefer more or less spending the areas are listed in Table 8.3. Although samples over time depended on different weighting methods, we report basic trends without re-weighting data. Instead, we conducted a series of regression models to confirm the validity of the changes we report below. ${ }^{2}$

2 Comparing survey results over time involves additional complications when the survey series changes; the earlier ISSP results $(1985,1990,1996)$ were weighted by population characteristics while the 2006 data are unweighted. We needed to be sure the trends we identified were not distorted by sample bias. To resolve this problem, we merged the samples and performed regressions for each of the spending areas, obtaining coefficients for each of the years of the survey results (1985 was the base category). These models allow us to control for gender, age and education - the most likely, straightforward sources of sampling differences 
As we can see in Table 8.3, there are three spending areas where Australians seek more spending than they did in the mid-1980s: the environment, health and education. Spending on the environment reflects the reality, and growing awareness, of dangerous climate change and the public's willingness to support major efforts by government to deal with this. Readers might be surprised to learn, however, that most of this shift in preferences took place back in 1990, during the first widespread awakening of ecological consciousness. By 2006, preferences for greater spending on the environment were much higher than they were in 1985, but perhaps disturbingly - given the state of the problemhave not fully recovered to 1990 levels.

Responses to health and education spending are equally interesting, but one could argue that these results, seeking greater public spending, reflect more polling 'noise' than real substance: voters of all persuasions consistently tell pollsters that governments don't do enough in these two huge portfolios. But trends are what matter here: Australians have become increasingly supportive of education and health spending. What explains this? For health, one possibility is that an older population will demand more health care - almost automatically. Yet our regression models did not find that support for more spending on health care increases with age. More likely is that population ageing increases perceptions in all age groups of the power of, and necessity for, more and more sophisticated medical care. Related, an affluent society - such as Australia - has increasingly high expectations of health care (Glennerster and Hills 1998; but see also Taylor-Gooby 1998). At the same time, perceptions of underfunding and poor maintenance and investment in hospital infrastructure have a bearing on public preferences. To explain increasing support for spending on education, it is reasonable to expect that as the skills, or at least the credentials, required to enter and advance within the labour market increase, so too will expectations of the education system, and of government spending. Again, other factors intervene: publicity about the quality of schooling, and neglect of the public school system, are likely factors in explaining support for more spending.

between weighted and unweighted data. How did results compare with the ones reported in Table 8.2? The trends in favour of greater spending on the environment, health and education were maintained - that is, these trends are real, and not products of sample bias. To compare the preferences of government spending in different years, the surveys of the years 1985, 1990, 1996 and 2006-07 were merged. 
8. A New Role for Government? Trends in social policy preferences since the mid-1980s

Table 8.3 Australian Spending Preferences by Policy Area, 1985-2007 (percentage preferring more)

\begin{tabular}{lrrrrr}
\hline & 1985 & 1990 & 1996 & 2007 & Change \\
\hline Environment & 32 & 64 & 48 & 59 & +27 \\
Health & 62 & 68 & 80 & 90 & +28 \\
Law enforcement & 67 & 68 & 67 & 67 & 0 \\
Education & 64 & 70 & 70 & 80 & +16 \\
Defence & 46 & 25 & 27 & 25 & -21 \\
Retirement & 55 & 55 & 50 & 54 & -1 \\
Unemployment benefits & 13 & 10 & 12 & 12 & -1 \\
Culture and the arts & 10 & 13 & 13 & 14 & +4 \\
& $(\mathrm{n} \geq 1448)$ & $(\mathrm{n} \geq 2356)$ & $(\mathrm{n} \geq 2086)$ & (n $\geq 2618)$ & \\
\hline
\end{tabular}

Sources: Australian Survey of Social Attitudes 2007; ISSP Role of Government module 1985, 1990, 1996, 2006.

We have some evidence from previous surveys to support the argument that perceptions of the declining quality of health care and public education are widespread. In 2003 and 2005, the AuSSA asked respondents whether they thought the standard of health services, including Medicare, and of public education had increased or decreased in the previous two years. In 2003, 59 per cent of respondents thought health service standards had decreased a little or a lot, and 42 per cent thought standards in public education had decreased (Gibson et al. 2004). Two years later, 51 per cent thought health standards had fallen, and 48 per cent thought public education standards had fallen (Wilson et al. 2006). (In both surveys, relatively small minorities of between 14 and 18 per cent of respondents believed that either health or education standards had improved.) Although we should interpret the perception of precipitous decline in standards over four years with caution, these findings clearly demonstrate that Australians have been concerned about the quality of health and public education in recent years. These perceptions - more than, say, perceptions of the generosity of government to the unemployed-are driving support for greater government investment.

What have not changed much are preferences for spending in other areas of the welfare state: unemployment spending and retirement. Falling unemployment between 1992 and 2006 most likely accounts for this lack of change; while broader welfare-supporting attitudes have been rising, falling joblessness (until recently) has pushed the unemployment problem down the list of public priorities. But, even when joblessness is high or rising, the Australian public remains fairly cool about spending more on the unemployed, although regression results suggest Australians are marginally warmer towards spending on unemployment than they were in the 1980s. Still, the Labor Government did not direct any of two 2008 spending packages - totalling \$14.4 billion and 
aimed at boosting the economy - towards the unemployed. The February 2009 stimulus plan also focused mainly on working families, small business and single parents. The goal clearly has been to prevent rising unemployment rather than to lift living standards for the already unemployed. ${ }^{3}$

More puzzling is the failure for preferences towards spending on retirement income to rise. As we mention above, other survey evidence from the AES 2007 data suggests strong support for spending more on pensions. Perhaps the 'retirement' label is too undifferentiated to capture an underlying reality: strong support for more spending on pensioners, but more limited support for spending on non-pensioner retirees (whom the public recognises benefited a good deal from tax expenditures available to self-funded retirees in the late Howard years) (Wilson, Meagher and Hermes 2012).

The only spending item to record a dramatic fall is defence. Recall that, in 1985, Cold War fears still held major currency with voters, doubtless adding to support for defence spending (for an overview of trends in defence attitudes, see Gibson and McAllister 2007). Notice that all of the fall in preferences occurred at the end of the Cold War period, in 1990. Although a number of post-Cold War conflicts have stimulated defence spending ambitions, none has been strong enough or long-lasting enough to return preferences for greater defence spending to Cold War levels.

Before we move on, it is worth noting one policy problem demanding significant spending that public discussion has recently centred on: the poor state of Australia's 'infrastructure'. This means different things to different people; for the public, poor infrastructure means rundown or inadequate schools, transport, hospitals and roads, while for business, it means inferior ports and telecommunications. The ISSP survey data do not directly ask about spending preferences on infrastructure but it appears from other sources that the local discussion of infrastructure problems does resonate in comparative survey research. Australians were much more likely to seek additional spending on infrastructure than respondents in India, China, the United States, Japan and Russia - as measured by the most recent AsiaBarometer (see Park 2008).

3 These are the $\$ 10.4$ billion 'economic security strategy' announced in October 2008 (Rudd and Swan 2008), the $\$ 4$ billion 'business investment partnership' announced in January 2009 (Rudd 2009b) and the $\$ 42$ billion 'Nation building and jobs plan' announced in February 2009 (Rudd and Swan 2009). 


\section{Government responsibility and government performance}

In the previous section, our focus was spending preferences - on what policy areas Australians prefer government to spend more or less on. In this section we explore some related, but more basic, questions about the role and performance of government. What social and economic activities do Australians believe the government should take responsibility for? Have Australians changed their views on the role of government over the past two decades? And how well do Australians rate the success of government action in some key areas? This section also takes advantage of ISSP data to compare what Australians think about the role of government with the views of citizens in other countries.

One important context for these questions is the political contention over the size of government that emerged in the wake of the economic crisis of the 1970s, and that has continued, if not raged, ever since. That economic crisis came towards the end of four decades of substantial growth in public spending in rich democracies. Governments had both expanded programs in areas in which they had previously been involved and taken on new responsibilities, and spending on social security and on human services, such as health and education, grew faster than spending in other areas (Lindert 2004; Wilensky 2002). Many of those on the 'small government' side of the debate blamed rising public spending, particularly social spending, for the economic crisis, and called for a reduction in the size and scope of government.

Debate about the size and scope is inevitably debate about whether the government should or should not be responsible for this or that activity, and if so to what extent. Accordingly, social researchers began to ask citizens about their perceptions of the role of government with the question: 'On the whole, do you think it should or should not be the government's responsibility to... [undertake the activities listed in the first column of Table 8.4].' Findings from these studies can be used to assess support for the redistributive activities of the welfare state, since several questions deal with social policy; to understand whether the public has taken up arguments for reducing the size and scope of government; and to explore the relationship between public opinion and policy structures in different welfare regimes (Jæger 2009; Svallfors 2003).

\section{Do Australians want a reduced role for government?}

Our analysis of spending preferences suggests that Australians do not seek a drastically reduced role for government, at least as measured by their willingness to pay more taxes and their desire to see more spending in some key policy areas. 
Table 8.4 shows Australians' responses on the related question of government responsibility over two decades. The survey invites respondents to choose whether an activity 'Definitely should be', 'Probably should be', 'Probably should not be' or 'Definitely should not be' the government's responsibility. To make it easier to compare years (and groups of countries later in the chapter), we have converted responses into a 10-point mean scale. On this scale, a higher score (above five) means that, on average, respondents think the government should take responsibility and a lower score (below five) means that, on average, respondents think the government should not take responsibility. The higher (lower) the score, the more (less) people think the government should take more responsibility.

Table 8.4 Australian Beliefs about the Role of Government, 1985-2007 (mean scores) ${ }^{*}$

\begin{tabular}{|c|c|c|c|c|c|}
\hline & 1985 & 1990 & 1996 & 2007 & $\begin{array}{l}\text { Change } \\
1985- \\
2007 * *\end{array}$ \\
\hline $\begin{array}{l}\text { Provide a job for everyone } \\
\text { who wants one }\end{array}$ & 5.2 & 4.7 & 4.9 & 4.5 & -0.7 \\
\hline Keep prices under control & 7.8 & 6.8 & 6.7 & 7.6 & -0.2 \\
\hline $\begin{array}{l}\text { Provide health care for } \\
\text { the sick }\end{array}$ & 8.4 & 7.7 & 7.9 & 9 & 0.6 \\
\hline $\begin{array}{l}\text { Provide a decent standard } \\
\text { of living for the old }\end{array}$ & 8.6 & 7.7 & 7.7 & 8.3 & -0.3 \\
\hline $\begin{array}{l}\text { Provide industry with the } \\
\text { help it needs to grow }\end{array}$ & 7.2 & 6.7 & 6.8 & 7 & -0.2 \\
\hline $\begin{array}{l}\text { Provide a decent } \\
\text { standard of living for the } \\
\text { unemployed }\end{array}$ & 5.5 & 5.1 & 5.6 & 5.2 & -0.3 \\
\hline $\begin{array}{l}\text { Reduce income differences } \\
\text { between rich and poor }\end{array}$ & 5.3 & 5.1 & 5.3 & 5.9 & 0.6 \\
\hline $\begin{array}{l}\text { Give financial help to } \\
\text { university students from } \\
\text { low-income families }\end{array}$ & n.a. & 6.9 & 7 & 7.6 & 0.7 \\
\hline $\begin{array}{l}\text { Provide decent housing for } \\
\text { those who can't afford it }\end{array}$ & n.a. & 6.3 & 6.1 & 6.6 & 0.3 \\
\hline \multirow{2}{*}{$\begin{array}{l}\text { Impose strict laws to make } \\
\text { industry do less damage to } \\
\text { the environment }\end{array}$} & n.a. & n.a. & 8.2 & 8.5 & 0.3 \\
\hline & $(n \geq 1440)$ & $(n \geq 2292)$ & $(n \geq 2038)$ & $(n \geq 2618)$ & \\
\hline
\end{tabular}

* 10 -point scale; higher values = more responsibility.

** For items added to the ISSP survey in 1990 (housing, student support) and 1996 (environmental laws), comparison over time takes the relevant first survey year as the starting point.

Sources: Australian Survey of Social Attitudes 2007; ISSP Role of Government module 1985, 1990, 1996. 
Focusing first on findings for 2007, we see very strong support among Australians for the government taking responsibility in some key social and economic policy areas: providing health care and environmental protection stand out, with scores of 9 and 8.5 out of 10 respectively, closely followed by a decent standard of living for the old (8.3). Support is considerably weaker when it comes to providing a decent standard of living for the unemployed (5.2) and reducing income differences (5.9). And on the question of government responsibility for providing jobs, Australians are, on balance, opposed (4.5). These three lowest-scoring activities are related, and responses show how much Australians frame the operation of the labour market, and a person's success or failure in it, in individualistic/market rather than social/ government terms (see also Meagher and Wilson 2008).

Because these questions have been asked four times since, we can assess whether Australians have become less supportive of government involvement in economic and social life overall, in the context of calls for smaller government. One way to do this is to compare the scores on each activity between 1985 and 2007. Looking down Column 6 of Table 8.4, it is difficult to see evidence of a general preference for reducing government involvement among Australians: for some activities, support for government taking responsibility has grown (health care, financial help to students, environmental protection); for others it has fallen (providing jobs, industry assistance, price control). Most show a pattern of mild fluctuation across the decades. Another approach is to compare a combined average score for all activities, which forms a simple measure of overall support for government intervention. In 1985, the combined average score for the seven activities included in the survey was 6.9. The combined average score for the same seven activities in 2007 is 6.8 . If we include all 10 activities asked about in the 2007 survey, we get an average score of 7.0. These findings suggest that, on balance, Australians' orientation to the role of government has been fairly positive and stable. The findings also accord with Michael Pusey and Nick Turnbull's (2005) conclusions about public opinion on market-oriented economic reform in Australia.

\section{Government responsibilities: How does Australia compare?}

Our task now is to put Australian beliefs about the role of government into international perspective. Figure 8.2 compares Australian beliefs with those of people in seven groups of countries, drawn from the rich democracies of East and West as well as from Eastern Europe and Latin America. ${ }^{4}$ (Values charted

\footnotetext{
4 Researchers have long been interested in the relationship between public opinion and the institutional structures of welfare states, and a rich body of research has accumulated in recent decades. Debates about the extent to which attitudes vary as much within as between welfare regimes have been important. Within the scope of a survey chapter such as this, we are not able to engage deeply with these debates. Recent work has confirmed that systematic differences both within and between regime types can be expected (Jæger 2009); our focus here is on between-regime differences. We extend previous work by including groups of Latin American and rich East Asian countries.
} 
for Australia are those from Column 5 of Table 8.4.) Western European, North American and Antipodean rich democracies are grouped into welfare regimes, following Esping-Andersen's (1990) typology, while the remaining countries are grouped geographically. ${ }^{5}$ Again, we use a 10-point scale and calculate mean scores for each activity for each group of countries. ${ }^{6}$ What does this comparison reveal? First, Australia and the other liberal welfare regimes stand out in their relative opposition to government intervention in the labour market and redistribution. Indeed, mean scores on 'provide a job for everyone' in Australia and in the group of other liberal countries are the only ones registering majority opposition to government involvement in any activity in any group of countries. ${ }^{7}$ This is not surprising: an individualistic and market-oriented approach to the labour market and income distribution is a defining characteristic of liberal welfare regimes, and is reflected both in attitudes and institutions.

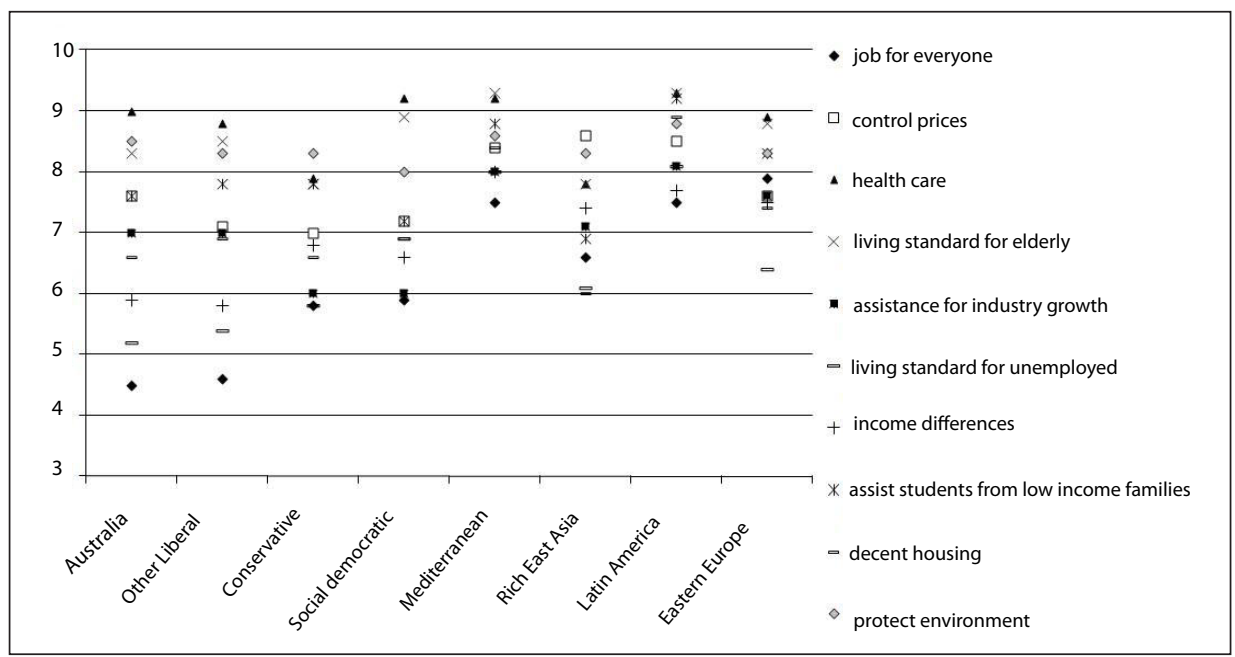

Figure 8.2 Beliefs about Government Responsibility, Australia and Other Welfare Regimes/Country Groups, 2006 (mean scores)

Sources: Australian Survey of Social Attitudes 2007; ISSP Role of Government module 2006.

Despite low scores on activities related to the labour market and redistribution in other liberal countries, respondents from these countries are, like Australians, on balance strongly supportive of a role for government in some activitiesnotably in health care, environmental protection and providing a decent living

5 We use Esping-Andersen's typology, but can include only those countries that participated in the ISSP 2006. Esping-Andersen classifies Australia as a liberal welfare state, although this has been contentious (Castles and Mitchell 1993). Appendix Table A8.1 shows the countries included in each group.

6 The means for country groups are not weighted for the size of the member countries.

7 Among the 30 individual countries included in the groups presented in Figure 8.2 only three had mean scores lower than five on any of the 10 activities surveyed in 2006: 4.1 for government responsibility for housing in Japan, 4.6 for providing a decent standard of living for the unemployed in the Czech Republic, and 4.8 for assistance to industry in Switzerland. 
standard for old people. This wide dispersal of scores-from 4.6 (jobs) to 8.8 (health care) - in liberal regimes suggests the lack of a general position on the role of government. By contrast, the distribution of scores in Mediterranean, Latin American and Eastern European countries is much more compressed. Respondents in these country groups strongly support government responsibility in all activities surveyed (minimum score overall is 7.4 for housing in Eastern Europe), with the single exception of lower support for providing a decent standard of living for the unemployed in Eastern Europe (6.4). Other groups of countries fall somewhere in between. Dispersal is moderate in rich East Asia and conservative countries, but support for government involvement is also moderate, with few scores exceeding 8.0 in either group. Perhaps surprisingly, dispersal is quite wide in social-democratic countries, which show very strong support for government involvement in health care and providing for older people, but quite low support, on average, for providing jobs and assisting industry.

Explaining these patterns is not entirely straightforward. In some cases, high scores express respondents' desire for governments to increase their responsibility in a given area - this is likely to be the case for most activities in Latin American and Mediterranean countries, where universal institutional supports for social and economic development are weak. In other cases, high scores are likely to express citizen support for, and desire for further commitment to, significant existing government responsibility; health care and provision for the elderly in social-democratic countries are examples here. When it comes to low scores, we have already pointed out how little support there is for intervention in the labour market and redistribution in liberal countries, and noted how these beliefs accord with comparatively low levels of government involvement in these activities. Yet support for government responsibility for job creation and supporting the living standards of the unemployed is also relatively weak in social-democratic countries. In these countries, governments have taken very significant responsibility in these policy areas, and so are likely to have more fully met demand for labour-market intervention.

We can explore these ideas a little further using a question the Role of Government survey asks respondents about how successful they think their government is in a range of activities. Four of the activities asked about correspond directly with those included with the question about government responsibility: health care, living standards for the old, fighting unemployment and protecting the environment. Figure 8.3 compares mean scores for these four activities for measures of both government responsibility and government success. 


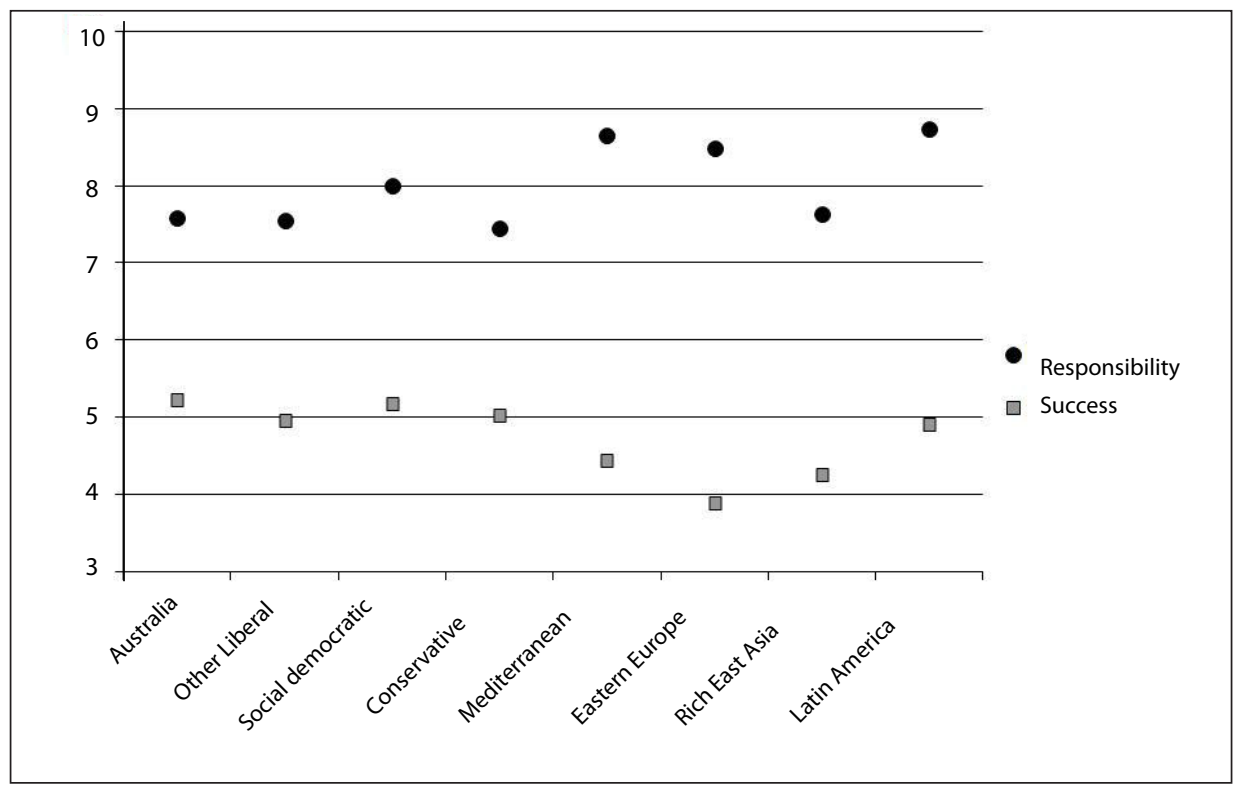

Figure 8.3 Beliefs about Government Responsibility and Perceptions of Government Success, Mean Scores by Regime Type, 2006

Sources: Australian Survey of Social Attitudes 2007; ISSP Role of Government module 2006.

First, note the rather lacklustre assessment respondents make, on average, of the success of government in these four activities. Just as for the government responsibility scale, a higher score (above five) means that, on average, respondents think the government is successful and a lower score (below five) means that, on average, respondents think the government is not successful. On average, government is considered unsuccessful in all groups of countries except the conservative and social-democratic regimes and in Australia, where it is considered only very marginally successful. Second, note the larger gap between perceptions of success and beliefs about responsibility in the groups we previously identified as having underdeveloped supports for social and economic development: Latin American and, to a lesser extent, Mediterranean countries. There is also a large gap between perceived success and beliefs about responsibility in Eastern European countries, where institutional supports have been greatly reduced since the fall of communism. This suggests at least some attachment among citizens to the supports developed in communist states, if not to the political repression they also experienced.

Clearly, attitudes and institutions are related in complex ways, and to understand these relationships we need knowledge of policy structures and institutional histories (Brooks and Manza 2007, 30-2). For example, we have mentioned the individualist orientation of liberal welfare states. This orientation is not simply a matter of values or culture; these are also countries where left-wing parties and unions had the 
most trouble, during the twentieth century, establishing institutions that would guarantee full employment and high levels of social protection for the unemployed, usually through active labour-market programs. Where left-wing parties and unions gained a strong foothold, as they did in social-democratic countries, they were able to establish institutions, such as the Ghent system. Under Ghent systems, unions control unemployment insurance. This institution encourages very high levels of union participation and high levels of support for collective welfare arrangements that are organised separately from the mainstream tax system.

In English-speaking countries, such institutions have not been established, and so the public, without experience of them, 'defaults' to private solutions. Further reducing pressure on English-speaking democracies to spend more on labourmarket solutions are falling rates of unemployment in recent years; supporters say this is the result of labour-market deregulation, but some economists have observed - for some time now - that debt-driven growth is behind this success (Schmitt 2000). How the economic crisis tests public orientations in liberal regimes about dealing with unemployment will be interesting to observe.

\section{The role of government: Does political orientation matter?}

Detailed analysis of the social structure of beliefs about the role of government is beyond the scope of this chapter; ${ }^{8}$ however, we conclude this section by briefly exploring whether political orientation makes a difference to beliefs about the role of government.

Figure 8.4 sets aside the issue of international variation to examine what relationship there might be between political orientation and beliefs about the role of government. The chart compares the mean scores between respondents identified with political parties across the spectrum from extreme left to extreme right with the average response overall. ${ }^{9}$ (In other words, the mean score overall for each activity is set at zero for the purposes of this comparison.) Two findings stand out. First, and unsurprisingly, there is a stark divide between the far left and the conservative right on government intervention in the labour market and redistribution; after all, these are the economic and social policy issues that define left and right orientations. We see, then, that those on the far left have higher than average scores in favour of government redistributing income,

8 For comparison of countries within welfare regime groups, see Evans (1998); Jæger (2009); and Svallfors (2003). Svallfors (2003) and Jæger (2009) also analyse variations between social groups, such as class and gender, within and between regimes.

9 Respondents to the ISSP are asked about which party in their country they affiliate with. To enable researchers to make cross-national comparisons, the ISSP derives a new variable by coding political parties in each country on the left-right scale (shown in Figure 8.5) when preparing the combined file with data for all countries. 
providing jobs and providing a decent standard of living for the unemployed, while those on the conservative right have lower than average scores for all activities measured here, but particularly for these three. Second, we see that the far right and the conservative right do not seem to cluster together, and that those on the far right are closer to the average, and even to the left, than they are to the conservative right. This finding likely reflects class cleavages on the right, such that the far right is dominated by disaffected working and lower middleclass voters, while the centre right is dominated by the wealthier middle class. The finding is also likely to reflect differences between countries in the political orientations of class groupings - far-left and far-right parties are virtually nonexistent in most liberal countries, for example.

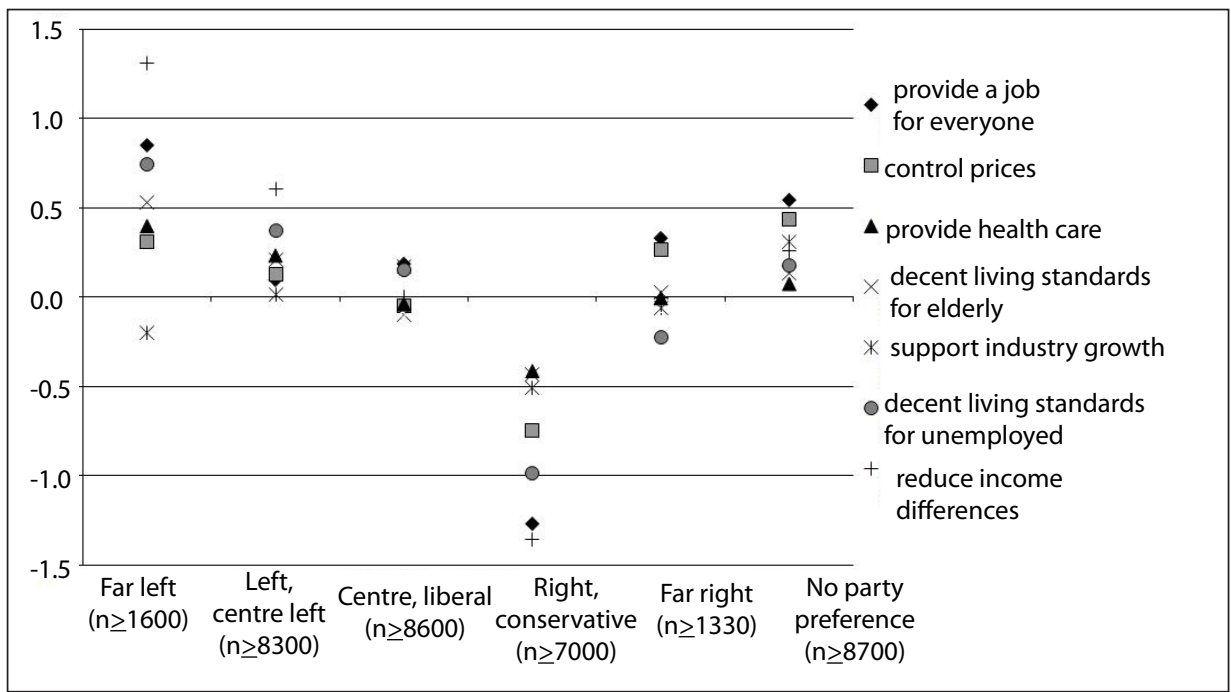

Figure 8.4 Perceptions of Government Responsibility, Difference from Mean Scores Overall by Political Party Orientation, All Respondents, 2006

Sources: Australian Survey of Social Attitudes 2007; ISSP Role of Government module 2006.

\section{Conclusion}

This chapter makes three claims. First, the mood for fiscal expansion-evident in survey findings for about 10 years - continues. The Rudd Labor Government's economic stimulus packages (December 2008 and February 2009), though designed to address an economic crisis, have chosen to reflate through spending rather than tax reductions - in accord with public preferences. Second, when we compare spending priorities of Australians today with those researchers found in the mid-1980s, we find that voters want more spending on education, health care and the environment. We speculate that perceptions of rundown education and health systems are major factors driving the strong spending preferences that have become a longer-term trend. Third, we find that Australian expectations 
of government look similar to other liberal welfare states: highly supportive of government provision of pensions and health care, increasingly supportive of assistance for low-income students, reducing income inequality and providing public housing, but less supportive of assistance to the unemployed and finding people jobs. But market solutions to maintaining employment have come under severe strain as a result of the economic crisis. How publics and governments across liberal regimes respond to these new threats will reveal something about the durability - or perhaps, adaptive dynamics - of the liberal model.

\section{References}

Brooks, Clem and Manza, Jeff. 2007. Why Welfare States Persist: The importance of public opinion in democracies. Chicago: University of Chicago Press.

Castles, Francis G. and Mitchell, Deborah. 1993. 'Worlds of welfare and families of nations'. In Families of Nations: Patterns of public policy in Western democracies, ed. F. G. Castles. Aldershot, UK: Dartmouth Publishing Company.

Esping-Anderson, Gøsta. 1990. The Three Worlds of Welfare Capitalism. Princeton: Princeton University Press.

Evans, Geoffrey. 1998. 'Britain and Europe: separate worlds of welfare?'. Government and Opposition 33: 139-270.

Gibson, Rachel and McAllister, Ian. 2007. 'Defence, security and the Iraq war'. In Australian Social Attitudes II: Citizenship, work and aspirations, eds David Denemark, Gabrielle Meagher, Shaun Wilson, Mark Western and Timothy Phillips, pp. 37-57. Sydney: UNSW Press.

Gibson, Rachel, Wilson, Shaun, Meagher, Gabrielle, Denemark, David and Western, Mark. 2004. Australian Survey of Social Attitudes 2003. Data file. Canberra: Australian Social Science Data Archives, The Australian National University.

Gillard, Julia. 2008. Introduction of the Fair Work Bill today. Media release. Canberra: Deputy Prime Minister's Office, Parliament House. $<$ http://www.deewr.gov.au/Ministers/Gillard/Media/Releases/Pages/ Article_081128_144403.aspx>

Glennerster, Howard and Hills, John. (eds). 1998. The State of Welfare: The economics of social spending. Oxford: Oxford University Press. 
Harding, Anne and Szukalska, Aggie. 1999. Making a Difference: The impact of government policy on child poverty in Australia, 1982 to 1997/9. Discussion Paper no. 42. Canberra: National Centre for Social and Economic Modelling.

Jæger, Mads Meier. 2009. 'United but divided: welfare regimes and the level and variance in public support for redistribution'. European Sociological Review (12 January).

Lindert, Peter. 2004. Growing Public: Social spending and economic growth since the eighteenth century. Cambridge: Cambridge University Press.

Meagher, Gabrielle and Wilson, Shaun. 2008. 'Richer, but more unequal: perceptions of inequality in Australia 1987-2005'. Journal of Australian Political Economy 61: 220-43.

Mishel, Lawrence, Bernstein, Jared and Shierholz, Heidi. 2008. The State of Working America 2008/9. Ithaca, NY: Cornell University Press.

Organisation for Economic Cooperation and Development (OECD). 2007. Revenue Statistics 1965-2006. Paris: Organisation for Economic Cooperation and Development. <http://oberon.sourceoecd.org/vl=1004325/cl=26/nw=1/rpsv/ cgi-bin/fulltextew.pl?prpsv=/ij/oecdthemes/99980169/v2007n3/s4/p84.idx>

Organisation for Economic Cooperation and Development (OECD). 2008. Growing Unequal? Income distribution and poverty in OECD countries. Paris: Organisation for Economic Cooperation and Development.

Park, Chong-Min. 2008. Public attitudes toward government spending in advanced and emerging market economies. Paper prepared for the AsiaBarometer 2008 Workshop, Chuo University, Tokyo, 17-18 December.

Pusey, Michael and Turnbull, Nick. 2005. 'Have Australians embraced economic reform?'. In Australian Social Attitudes: The first report, eds Shaun Wilson, Gabrielle Meagher, Rachel Gibson, David Denemark and Mark Western, pp. 161-81. Sydney: UNSW Press.

Rudd, Kevin. 2009a. 'The global financial crisis'. The Monthly (42)(February).

Rudd, Kevin. 2009b. Building Australia's future - a \$4 billion Australian business investment partnership to support Australian jobs. Media release, 24 January. Canberra: Parliament House. <http://www.pm.gov.au/media/ Release/2009/media_release_0771.cfm>

Rudd, Kevin and Gillard, Julia. 2007. Forward with Fairness: Labor's plan for fairer and more productive Australian workplaces. Canberra: Australian Labor Party. <http://www.alp.org.au/download/now/forwardwithfairness.pdf> 
Rudd, Kevin and Swan, Wayne. 2008. Economic security strategy. Joint press release with the Treasurer, Wayne Swan, 14 October. Canberra: Parliament House. <http://www.pm.gov.au/media/release/2008/media_release_0550.cfm>

Rudd, Kevin and Swan, Wayne. 2009. \$42 billion nation building and jobs plan. Joint press release with the Treasurer, Wayne Swan, 3 February. Canberra: Parliament House. <http://www.pm.gov.au/media/Release/2009/media_release_0784.cfm>

Schmitt, J. 2000. 'Demand drives US jobs success'. The Guardian, 4 September. $<$ http://www.epi.org/publications/entry/webfeatures_viewpoints_ demand_usjobs/>

Smith, Tom. 1987. 'The polls - a report: the welfare state in cross-national perspective'. Public Opinion Quarterly 51: 404-21.

Spies-Butcher, Ben and Stebbing, Adam. 2008. Beyond the targeted welfare state? How recent developments in tax expenditures are transforming Australian welfare. Paper presented to the conference on A Future for the Australian Welfare State? Continuity and Change from Howard to Rudd, Macquarie University, Sydney, 25 July.

Stimson, James. 1991. Public Opinion in America: Moods, cycles, and swings. Boulder, Colo.: Westview Press.

Stimson, James. 2004. Tides of Consent: How public opinion shapes American politics. New York: Cambridge University Press.

Svallfors, Stefan. 2003. 'Welfare regimes and welfare opinions: a comparison of eight Western countries'. Social Indicators Research 64: 495-520.

Taylor-Gooby, Peter. 1998. “Things can only get better": expectations and the welfare state'. Policy \& Politics 26: 471-6.

UNICEF. 2007. Child Poverty in Perspective: An overview of child well-being in rich countries, Innocenti report card 7. Florence: UNICEF Innocenti Research Centre. <http://www.unicef-irc.org/publications/pdf/rc7_eng.pdf>

Vu, Q. N., Harding, A. and Percival, R. 2008. A growing gap? Trends in economic wellbeing at the top of the spectrum in Australia. Paper prepared for the 30th General Conference of the International Association for Research on Income and Wealth, Portoroz, Slovenia, 29 August. <http://www.iariw.org/ papers/2008/harding.pdf>

Wilensky, Harold. 2002. Rich Democracies: Political economy, public policy, and performance. Berkeley: University of California Press. 
Wilson, Shaun, Gibson, Rachel, Meagher, Gabrielle, Denemark, David and Western, Mark. 2006. The Australian Survey of Social Attitudes, 2005: User's guide. Canberra: Australian Social Science Data Archive, The Australian National University.

Wilson, Shaun, Meagher, Gabrielle and Breusch, Trevor. 2005. 'Where to for the welfare state?' In Australian Social Attitudes: The first report, eds Shaun Wilson, Gabrielle Meagher, Rachel Gibson, David Denemark and Mark Western, pp. 101-21. Sydney: UNSW Press.

Wilson, Shaun, Meagher, Gabrielle and Hermes, Kerstin. (2012). 'The social division of welfare knowledge: policy stratification and perceptions of welfare reform in Australia'. Policy and Politics 40: 323-46.

\section{Appendix 8.1}

\section{Table A8.1 Country Groups}

\begin{tabular}{|c|c|}
\hline Liberal & $\begin{array}{l}\text { [Australia], Canada, Ireland, New Zealand, United Kingdom, United } \\
\text { States of America }\end{array}$ \\
\hline Social democratic & Denmark, Finland, Norway, Sweden, Netherlands \\
\hline Conservative & France, Germany (West), Switzerland \\
\hline Mediterranean & Portugal, Spain \\
\hline Eastern Europe & $\begin{array}{l}\text { Croatia, Czech Republic, Germany (East), Hungary, Latvia, Poland, } \\
\text { Russia, Slovak Republic, Slovenia }\end{array}$ \\
\hline Rich East Asia & Japan, South Korea, Taiwan \\
\hline Latin America & Chile, Uruguay, Venezuela \\
\hline
\end{tabular}

Source: ISSP Role of Government module 2006. 


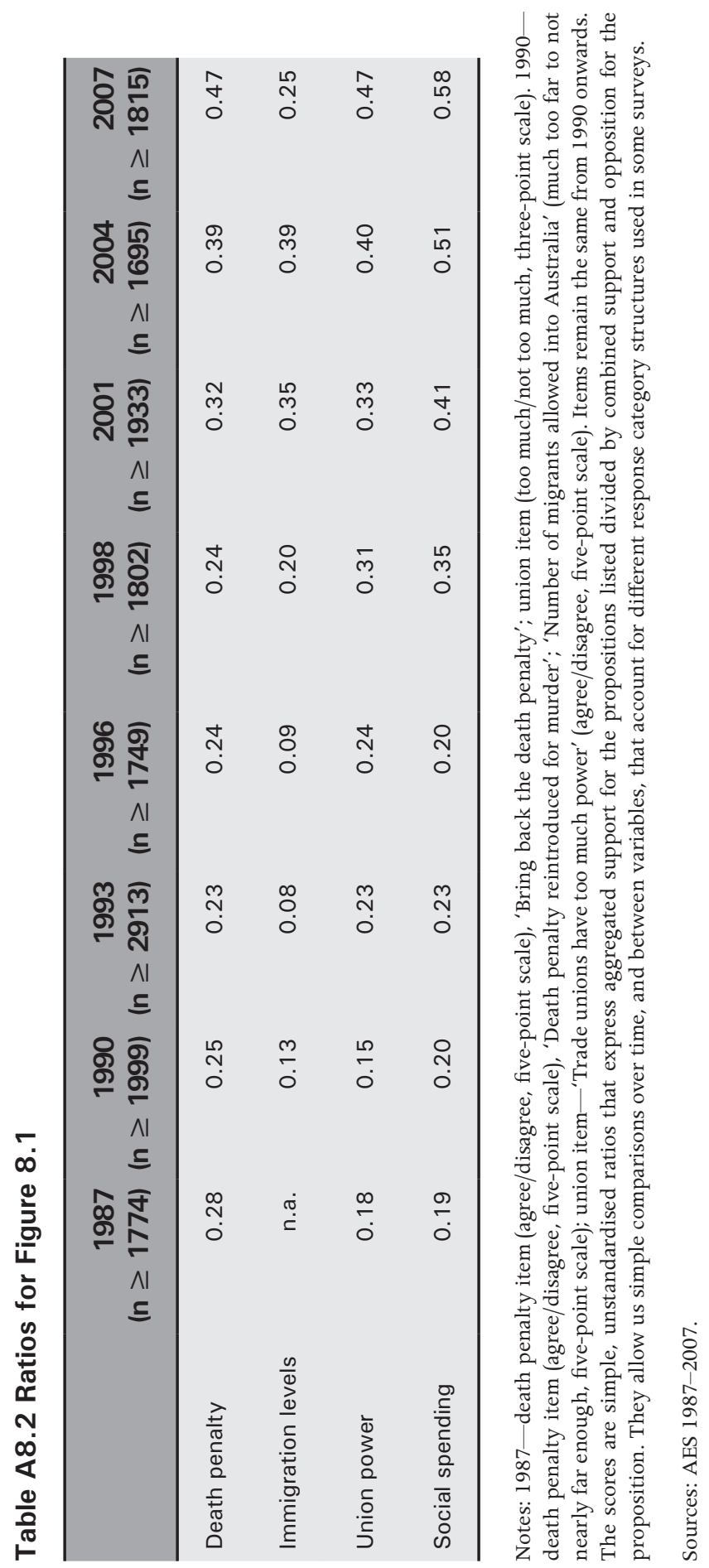

